\title{
Plant collections endangered in Eastern Europe and Russia
}

Paris. More than half a million varieties of 2,500 plant species stored in gene banks in Eastern Europe and the former Soviet Union are at risk, according to a report issued last month by the Food and Agriculture Organisation and the International Board for Plant Genetic Resources. Immediate

\section{IMAGE UNAVAILABLE FOR COPYRIGHT REASONS}

\section{The Vavilov Institute in St Petersburg}

international assistance is needed to avoid the damage that could be caused from a depressed economy and a series of decisions to privatize plant breeding institutes without providing continued public funding for the gene banks associated with them.

The Soviets have collections unmatched elsewhere because of the work of Nikolai Vavilov, the first president of the Academy of Agricultural Sciences, beginning in the 1920 s. But with funding for agricultural research programmes being reduced by as much as 80 per cent since the breakup of the Soviet Union, his emphasis on plant genetic resources is being abandoned.

Gene banks in the former Soviet Union are most at risk because of the lack of longterm storage facilities, at $-20^{\circ} \mathrm{C}$, for nearly 350,000 accessions at the Vavilov Institute in St Petersburg and its 17 experimental stations. More than half the collection is kept in paper bags at room temperature in St Petersburg, and another 120,000 items are stored at $5-8^{\circ} \mathrm{C}$ at Kuban. These accessions must be regrown, multiplied and dried every five years, a process that is labour intensive, and there are insufficient funds for equipment to extend their life.

The fate of a quarter of the Soviet collection, mostly subtropical species, is even more uncertain. These stations are owned by the newly independent states but are poorly equipped compared with gene banks at Kuban and St Petersburg. Moreover, the new governments are unlikely to have either the resources or the interest to maintain this germplasm.

There is less risk that the Eastern Euro- pean collections will disappear because most are held in long-term storage facilities. But the harsh economic conditions still pose a serious threat: for example, at the Institute for Plant Genetic Resources in Sadovo, Bulgaria, with tens of thousands of accessions, compressors in one of the three cold rooms are broken and those in a second room are unreliable. If the remaining cold room ceases to function, the institute does not have hard currency to buy the needed Russian spare parts.

In addition, most of the collections do not have funding commitments beyond the end of the year. With the institutes now obliged to produce and to sell seed to pay for essential staff and operating expenses, many are terminating support for gene banks. The idea that such facilities should be supported by the government has not been embraced by the governments of Eastern Europe.

Although the situation appears grim, a relatively small infusion of cash could reap large dividends. Emile Frison, group leader in Europe for the plant genetics resources board, estimates that " $\$ 2.5$ million over four to five years" would protect a multi-billiondollar investment. He says that such a rescue package might buy enough time to persuade the relevant governments that germplasm collections require public funds.

Some money is forthcoming. The US Agriculture Department has agreed to spend $\$ 90,000$ in the next three years to develop computing facilities at the Vavilov Institute. Although the gene banks have been carefully compiled and monitored, little of the information is on computers and available for dissemination. The entire St Petersburg collection, for example, is contained in one set of handwritten catalogues. The US Agency for International Development has promised $\$ 400,000$ contingent on contributions from other countries, and the United Nations Development Programme has committed as much as $\$ 100,000$. The World Bank has asked the plant genetics board to coordinate the flow of aid to these collections to make sure that the money goes to those most in need.

European countries are broadly supportive of preserving the collections but it is too soon to say how much money, if any, will be forthcoming. Norway, for example, has suggested that any aid should be part of an effort to rescue germplasm of global significance rather than one intended primarily to preserve a research collection. Declan Butler
CHINA IN BRIEF

Beijing. Construction could begin as early as 1994 on China's controversial Three Gorges Dam approved earlier this year (see Nature 356, 736; 1992). The project is being designed in three parts - the dam and related facilities, a plan for the resettlement of more than one million people and a network to transmit electricity to eastern and central China - and Yang Zhen-Huai, water conservancy minister, said last month that the overall design for the dam is almost completed and will be unveiled next year. The government has already built a dedicated railway line to the remote and mountainous site and will, by the end of the year, have spent more than 3 billion yuan (US $\$ 550$ million) on new homes for those to be relocated. Opposition to the project persists, but the Chinese press has been unwilling to publicize their concerns.

In a major relaxation of its decadelong grip on graduate education, the Chinese State Education Commission will allow institutions of higher education to enrol students whose fees are paid by industry or who are self-supporting. Selected institutions will also be allowed to use state research money to fund graduate students. Under the present system, which has awarded 21,000 master's degrees and 7,000 doctora degrees since 1981, the commission selected each student and, upon graduation, assigned them to a job. The new rules will make universities more responsive to the demand for highly educated personnel by allowing other enterprises to sponsor students or having students pay their own way and be free to find work after they graduate. The government now supports 80,000 graduate students a year, a figure expected to shrink under the new system.

China's first institution to train foreigners in traditional medicine and acupuncture opened last month in Tianjin, the country's third largest city. The international Coliege of Chinese Traditional Medicine hopes eventually to enrol 500 foreign students, divided among undergraduate, graduate and short-term advanced study students. The college is authorized by the government to grant master's degrees in eight specialities and a doctoral degree in acupuncture.

The Chinese Academy of Sciences may elect members from outside the country under a new constitution approved earlier this year. Internationally renowned scientists who have made important contributions to the country's scientific and technological progress will be considered in future elections, to be held every two years. Another change on the horizon is the creation of a freestanding academy of engineering and technology sciences. You Qin L 